\title{
ANTIMICROBIAL ACTIVITY OF THE ESSENTIAL OIL OF ZANTHOXYLUM AVICENNAE
}

\author{
Putri Sri Andila
}

\begin{abstract}
ABSTRAK
Minyak atsiri Zanthoxylum avicennae (Lam.) DC diektrak dari organ daun dan buah tanaman koleksi Kebun Raya "Eka Karya" Bali. Spesies ini dikoleksi dari Nusa Tenggara Barat pada 15 Juni 1993, dan kemudian di tanam di Kebun Raya "Eka Karya" Bali sejak 15 Desember 1993. Tujuan dari penelitian ini adalah untuk menggali sifat antibakteri dan antifungi dari minyak atsiri daun dan buah Z. avicennae. Untuk pengujian antimikroba, kedua minyak atsiri diuji dengan lima jamur patogen tanaman, yaitu Fusarium oxysforum(+), F. solani(+), Aspergilus niger(+), Collectotricum sp.(+), and Cladosporium sp. dan empat bakteri manusia yaitu Eschericia coli ATCC 43894, Salmonella typhimurium, E. coli (strain isolasi klinis), dan Staphylococcus aureus. Hasil penelitian mengungkapkan bahwa kedua minyak atsiri Z. avicennae (Minyak daun dan Buah) memiliki aktivitas antifungi yang kuat terhadap kelima jamur uji. Untuk uji antibakteri, Minyak atsiri daun menunjukkan hasil positif aktivitas antibacteri terhadap Eschericia coli, tetapi tidak terhadap bakteri Staphylococcus aureus. Sedangkan minyak atsiri buah menunjukkan hasil positive aktivitas antibakteri terhadap Shalmonella thipymurium and Eschericia coli atcc 43894.
\end{abstract}

Kata kunci : Zanthoxylum avicennae, jamur patogen tanaman, bakteri, minyak atsiri; antimikroba.

\begin{abstract}
The essential oils of Zanthoxylum avicennae (Lam.) DC. was extracted from leaves and fruits harvested from a plant collection at Bali Botanic Garden, collected from West Nusa Tenggara, on June 15 1993, and planted at Bali Botanic Garden on December 15, 1993. The aim of this study was to investigate the antibacterial and antifungal activities of the leaves and fruit essential oils of this Z. avicennae. For antimicrobial assay, both of essential oils were examined five phytopathogenfungi, among other: Fusarium oxysforum (+), F. solani (+), Aspergillus niger (+), Colletotrichum sp.(+), and Cladosporium sp. and four strain human bacterial, they were Escherichia coli ATCC 43894, Salmonella typhimurium, E. coli (Clinically isolated strain), and Staphylococcus aureus. The result revealed that the leave and fruit oils of Z. avicennae had strong antifungal activities against those phytopathogenfungi. For the antibacterial assay, the leaf oil had positive antibacterial activity against Escherichia coli, but not to Staphylococcus aureus, while the fruit oil exhibited positive antibacterial against Salmonella thipymurium and Escherichia coli ATCC 43894.
\end{abstract}

Keywords: Zanthoxylum avicennae, phytopathogenfungi, bacterial, essential oil; antimicrobial.

\section{INTRODUCTION}

Rutaceae was comprised of 150 genera with the chief genus of this family are Citrus, Zanthoxylum, Ruta, Ptelea, Murraya and Fortunella (Siddique et al., 2012). Most of the Rutaceae family are an aromatic plant with containing a complex mixture of the volatile compound in its organs (such as Fruit, Leave, Bark and Seed ) (Aziz et al., 2010). Previous studies showed that the members of the Rutaceae family revealed various biological activities, for example antimicrobial (Ali et al., 2008; Aziz et al., 2010), antidiarrhoeal (Mandal et al., 2010), antioxidant ( $\mathrm{Su}$ et al., 2003; Wansi et al., 2006), antiprotozoal (Severino et al., 2009) and etch. Because of that, the Rutaceae have been used for any purpose, such as parfumery, gastronomy, traditional and modern medicine, and etch (Supabphol and Tangjitjareonkun, 2014). Genus Zanthoxylum (Rutaceae family) comprised of 200 species were distributed worldwide in the tropical and temperate region in America, Africa, Asia 
and Australia (Ruth, 2011). This genus is aromatic deciduous tree and shrub, and traditionally have been used for traditional medicine, perfumery, pharmaceutical and etch (Negi et al., 2011).

Zanthoxylum avicennae (Lam.) DC locally named Ying Bu Bo (Taiwan) is a small tree to $13 \mathrm{~m}$, dioecious, and evergreen, belonging to the Zanthoxylum genera. It is distributed mainly in dry forests, thickets and on open slopes at an altitude of up to 1630 metres above sea level, in India, China, Taiwan, and South East Asia (Hartley, 1966; Liu et al., 2014; Dai, et al., 2012). For a long time, Z. avicenna was used traditionally for various purposes in some regions, such as an important folk medicine for rheumatism, abdominal pain, jaundice, chronic hepatitis and the common cold in China(Cho et al., 2012, , Liu et al., 2014), as spices and flavouring agents in South East Asia(Seidemann, 2005; Cho et al., 2012), and as a digestive tonic in Vietnam (Chi, 1997).

Z. avicennae contains some chemical components in its essential oil and extract which has a high potential for pharmaceutical, pesticide, spice, and the food flavour industry (Thuy et al., 1999). So far, the research of antibacterial and antifungal activities the leaves and fruit essential oils of $Z$. avicennae had reported limitedly. There is a scientific paper reported that the volatile leaf oil of $Z$. avicennae has strong anticancer and antimicrobial activity on plant pathogenic fungus (Lin et al., 2014). Therefore, this study aimed to examine the antimicrobial activities of $Z$. avicenna essential oils (Fruit and leaves) against human bacterial dan phytopathogen fungi.

\section{MATERIAL AND METHOD}

\subsection{Plant material preparation}

The fresh fruits and leaves of Z. avicennae were obtained from the Bali Botanic Garden plant collection in March 2016. This plant was collected from natural forest, Batulanteh Mountain, West Nusa Tenggara, Indonesia on June 15, 1993, and planted at Bali Botanic Garden on December 15 1993. The plant was identified by a taxonomist of Bali Botanic Garden, Mr Ida Bagus Ketut Arinasa, M.Si and was deposited in the herbarium known as Tabanan Hortus Botanicus Baliense (THBB).

\subsection{Isolation of essential oil}

The 100 gram sample of fresh leaves and fruits of Z. avicennae was extracted by hydrodistillation for five hours using a Pudak Scientific apparatus. The aqueous emulsion was separated by a Duran Schott separator and produced a yellowish viscous essential oil.

\subsection{Microorganism strain and growth condition}

Three gram negative and one gram positive human pathogen bacteria and five plant pathogen fungi were tested for antibacterial and antifungal activity. They were Eschericia coli ATCC 43894, Salmonella typhimurium, Eschericia coli (Clinically isolated strain), Staphylococcus aureus, Fusarium oxysforum, Fusarium solani, Aspergillus niger, Aspergillus niger, Colletotrichum sp., and Cladosporium sp. For antimicrobial assay, the bacterial culture collection was stored in glycerol $(10 \% \mathrm{v} / \mathrm{v})$ at $-20^{\circ} \mathrm{C}$ and the overnight culture incubated in a nutrient broth at $37^{\circ} \mathrm{C}$. While for antifungal assay, the antifungal culture collections were stored on an agar slant of Difco ${ }^{\mathrm{TM}}$ Potatoe Dextrose Agar at $4^{\circ} \mathrm{C}$ and regrown every two months at room temperature. The overnight cultures on agar slant were diluted in sterile distilled water before being used in the experiment.

\subsection{Antibacterial assay}

Antibacterial activity was conducted by the disc diffusion assay method (Klancnik et al.,2010; Salah-Fatnassi et al.,2016) by modifying the treatment concentration. For the antibacterial disc 
diffusion assay, $100 \mu \mathrm{l}$ of each bacterial suspension (consisted of $2.10 \times 10^{9} \mathrm{cfu} / \mathrm{ml}-2.25 \mathrm{x}$ $10^{9} \mathrm{cfu} / \mathrm{ml}$ for each strain) was spread uniformly across a nutrient agar plate in a Petri dish. Two sterile paper disks (Whatman paper disc $6 \mathrm{~mm}$ in diameter) were placed on the surface of the agar plate and impregnated with $20 \pi \mathrm{l}$ of the fruit essential oil of $Z$. avicennae (100\% concentration). Then, agar plates were incubated for 24 hours at $37^{\circ} \mathrm{C}$, and the result of antibacterial activities was determined by observing the inhibition zone around the paper disc. Each treatment was repeated four times. Paper discs impregnated with sterile distilled water served as the negative control.

\subsection{Antifungal assay}

The antifungal assay of $Z$. avicennae essential oil was carried out by the disc diffusion assay method (Dellavalle et al., 2011). Spores of $Z$. avicennae were obtained from culture on PDA slant after a seven day incubation (Broekaert et al., 1990) and dissolved in sterile distilled water. The sporangial suspension $(1 \mathrm{~mL})$ was inoculated into unsolid PDA plate (medium temperature of about $45-50^{\circ} \mathrm{C}$ ), and homogenised. The plates were left standing for 40 minutes at $27^{\circ} \mathrm{C}$ to allow the mixture of PDA and spores to compact. After which two paper discs (Whatman paper disc 6 $\mathrm{mm}$ in diameter)were put on the PDA plate surface, and then $20 \pi \mathrm{l}$ of the fruit essential oil of $Z$. avicennae (100\% concentration) was dripped on the paper disc. The Petri dishes were incubated in room temperature $\left(27^{\circ}-30^{\circ} \mathrm{C}\right)$ and the antifungal activity was observed after three days of incubation. These treatments were carried out in triplicate. The antifungal activity was determined on the basis of a presence or absence of fungal growth inhibition.

\section{RESULT AND DISCUSSION}

Antimicrobial assay of essential oil of the fruit and leaves essential oils of Z. avicennae was reported in table 1 . In this study, both essential oils were examined for antifungal activities against five phytopathogenfungi, among other: Fusarium oxysforum(+), F. solani(+), Aspergillus niger(+), Colletotrichum sp.(+), and Cladosporium sp. (+). The result showed that both of leave and fruit essential oil of Z. avicennae (pure essential oils with $100 \%$ concentration) had strong antifungal activities against those phytopatogenfungi, it was proved by there was no fungus grew in the PDA media compared to negative control. The fruit and leaves essential oil of Z. avicennae with $100 \%$ concentration have totally inhibited the fungus growth on the PDA plate.

For the antibacterial assay, the fruit essential oil of Z. avicenna was tested with two human bacterial, they were Escherichia coli ATCC 43894 and Salmonella typhimurium (Figure 1). While the leaves essential oil was examined againts Eschericia coli and Staphylococcus aureus (Figure 2). The result revealed that the fruit essential oil of $Z$. avicenna exhibited positive antibacterial activities against Eschericia coli ATCC 43894 and Salmonella typhimurium with diameter of inhibition zones $17.23 \pm 1.91 \mathrm{~mm}$ dan $14.87 \pm 0.15 \mathrm{~mm}$. While the leaves essential oil performed positive antibacterial against Eschericia coli with inhibition zone diameter $20.45 \pm 0.21$, but negative antibacterial activities againts Staphylococcus aureus.

As per our knowledge, the antimicrobial activities of Z. avicennae fruit essential oil have been reported for the first time. However, a study about leaf essential oil antifungal activities of $Z$. avicennae had been reported by Zhang et al. (2014) and Lin et al. (2014). That study revealed that the leaf essential oils of $Z$. avicennae were active as antibacterial (Zhang et al., 2014) and as antifungal against Botrytis cinerea, Exerohilum turcicum, Rhizoctonia solani AG1-IA, $F$. graminearum, Sclerotinia sclerotiorum, $F$. oxysporum, $R$. solani, and $F$. graminearum (Lin et al. 2014).

Table 1. Antibacterial and antifungal activities of the fruit essential oil of Z. avicennae

\begin{tabular}{|c|c|c|c|}
\hline Microorganism & Material & $\begin{array}{c}\text { Antibacterial } \\
\text { Activity }\end{array}$ & $\begin{array}{c}\text { Inhibition Zone } \\
(\mathrm{mm})\end{array}$ \\
\hline
\end{tabular}




\begin{tabular}{|l|c|c|c|}
\hline Gram negative bacteria & & & \\
\hline Escherichia coli ATCC 43894 & Fruits EO & + & $17.23 \pm 1.91$ \\
\hline Salmonella typhimurium & Fruits EO & + & $14.87 \pm 0.15$ \\
\hline Escherichia coli & Leaves EO & + & $20.45 \pm 0.21$ \\
\hline Gram - positive bacteria & & & $0.00 \pm 0.00$ \\
\hline Staphylococcus aureus & Leaves EO & - & NI \\
\hline Yeast & & & NI \\
\hline Fusarium oxysforum & Fruits and Leaves EO & + & NI \\
\hline Fusarium solani & & & NI \\
\hline Aspergillus niger & Fruits and Leaves EO & + & NI \\
\hline Colletotrichum sp. & Fruits and Leaves EO & + & + \\
\hline Cladosporiumsp. & Fruits and Leaves EO & + & \\
\hline
\end{tabular}

Note: NI, not identified because there were not pathogenic fungus which could grow in PDA plate.

By comparison, several previous studies about antibacterial and antifungal activities in other species of Zanthoxylumspp. have been reported for many years, They are Z. chalybeum (Olila et al., 2001), Z. budrunga (Islam et al., 2001), Z. armatum (Wazir et al., 2014; Alan and Saqib, 2017), Z. tingoassuiba (Detoni et al., 2009), Z. rhetsa (Tantapakul et al., 2012),Z. acanthopodium (Parhusip., 2005), Z. holtizianum(Runyoro et al.,2017), Z. lindense (Runyoro et al.,2017), Z. bungeanum maxim (Zhang et al.,2014), Z. heitzii (Overgaard et al.,2014), Z. piperitum (Kim et. al.,2014), Z. rhoifolium (Tavares et. al.,2014), Z. acanthopodium (Devi et al., 2015), Z. alatum (Guleria et al., 2013), Z. tetraspermum (Nissanka et al., 2001), Z. caudatum (Nissanka et al., 2001), Z. ovalifolium (Pavani et al., 2015), Z. zanthoxyloides (Nana et al., 2015), Z. tingoassuiba (Costa et al.,2016), $Z$. budrunga (Rahman et al.,2008), Z.myriacanthum var. Pubescens (Li et al., 2014), and Z. leprieurii (Syn. Fagara leprieurii) (Misra et al., 2013)

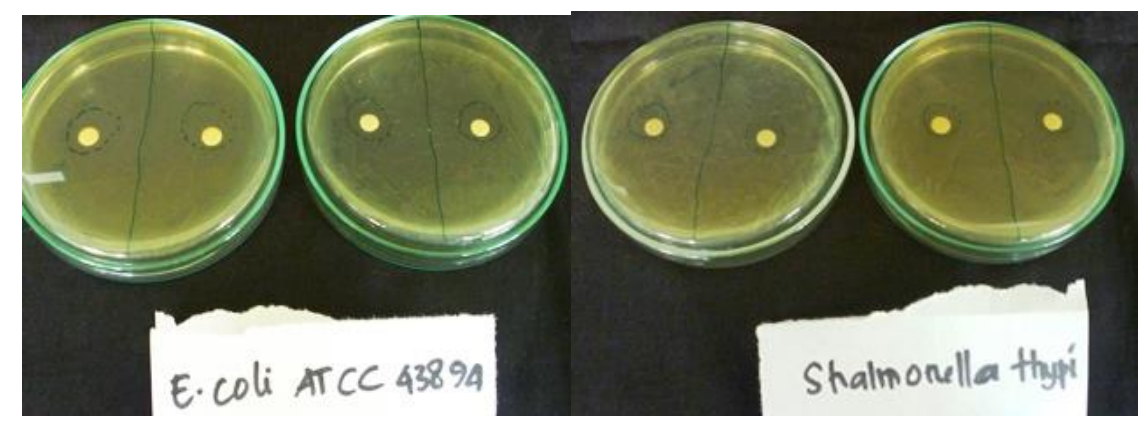

Figure 1. the fruit essential oil of Z. avicennae was tested with two human bacterial, they were Escherichia coli ATCC 43894 and Salmonella typhimurium

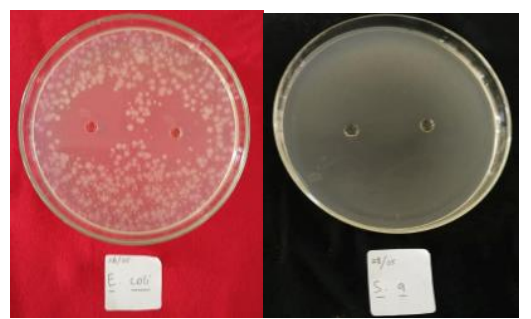

Figure 2. the fruit essential oil of Z. avicenna was tested with two human bacterial, they were Escherichia coli and Staphylococcus aureus

\section{CONCLUSION}

The essential oils of (The leaves and fruit oil) were tested for antimicrobial activity against five phytopathogenfungi and four human bacteria, including gram-positive cocci and gram-negative 
rods. Both the leaves and fruit oil exhibited positive antifungal against those phytopathogenfungi. But for antimicrobial assay, The leaves oil inhibitory to Escherichia coli, but not to staphylococcus aureus, while the fruit oil was inhibitory to Shalmonella thipymurium and Escherichia coli ATCC 43894.

\section{Acknowledgement}

The authors would like to say thank to Essential Oil Reseach Group at"Eka Karya" Botanic Garden- Bali- Indonesian Institute of Science for funding this research (DIPA-2016). We extend our highly appreciation to Dr. Meity Proborini, M.Sc, Dr. Retno Kawuri, M.Sc, and I Wayan Nursini, for providing facility to carryout antimicrobial study and sharing their opinion about the microbial context.

\section{REFERRENCES}

Ali, M.S., S. Fatima, M.K. Pervez (2008) Haplotin: A New Furanoquinoline from Haplophyllum acutifolium (Rutaceae). J. Chem. Soc. Pak. Vol. 30, pp. 775-779.

Aziz, S.S.S.A, M.A. Sukari, M. Kitajima, N. Aimi, N.J. Ahpandi (2010), Coumarins from Murraya paniculata (Rutaceae). Malaysian .J Anal. Sci. Vol.14, pp. 1-5.

Broekaert, W.F., F.R.G. Terras, B.P.A. Cammue, J. Vanderleyden (1990) An automated quantitative assay for fungal growth inhibition. FEMS Microbiology Letters. Vol. 69: Nu. 1-2, pp. 55-60.

Chi. V.V. (1997) Vietnamese Medical Plant Dictionary. Ha Noi Medicine Pub.

Cho, J.Y., T.L. Hwang, T.H. Chang, Y.P. Lim, P.J. Sung, T.H. Lee, J.J. Chen (2012) New coumarins and anti-inflammatory constituents from Zanthoxylum avicennae. Food Chemistry. Vol. 135: Num. 1, pp. 17-23.

Costa, R.S., M.O. Lins, M.L. Hyaric, T.F. Barros, E.S. Velozo (2016) In vitro antibacterial effects of Zanthoxylum tingoassuiba root bark extracts and two of its alkaloids against multiresistant Staphylococcus aureus. Rev. Bras. Farmacogn. Vol. 27: Num. 2, pp. 195-198.

Dai, D.N., N.X. Luong, T.D. Thang, L. Jirovetz, M. Hoeferl, E. Schmidt (2012) Chemical composition of the essential oil of Zanthoxylum avicennae (Lam.) DC leaves (Rutaceae) from Vietnam. J. Essent. Oil-Bearing Plants. Vol. 15: Num. 1, pp. 7-11.

Dellavalle, P.D., A. Cabrera, D. Alem, P. Larrañaga, F. Ferreira, M.D. Rizza (2011). Antifungal activity of medicinal plant extracts against phytopathogenic fungus Alternaria spp. Chilean J.Agric. Res. Vol. 71: Num. 2, pp. 231-239.

Hartley, T.T.G. (1966). A Revision of The Malesian species of Zanthoxylum (Rutaceae). J. The Arnold Arboretum. Vol. 47: Num. 3, pp. 171-219.

Klancnik, A., S. Piskernik, B. Jersek, S.S. Mozina (2010). Evaluation of diffusion and dilution methods to determine the antibacterial activity of plant extracts. J. Microbiol. Methods. Vol. 81: Num. 2, pp. 121-126.

Li, R., J.J. Yang, Y.X.M. Zhao, K.L. Ji, S.P. Zhang, Y.K. Xu, H.B. Hu (2014) Chemical composition, antimicrobial and anti-inflammatory activities of the essential oil from Maqian (Zanthoxylum myriacanthum var. pubescens) in Xishuangbanna, SW China. J. Ethnopharm.Vol. 158: Num. A, pp. 43-48.

Lin, Y., W. Han, W.C. Ge, K. Yuan (2014) Chemical composition of the volatile oil from Zanthoxylum avicennae and antimicrobial activities and cytotoxicity. Pharmacogn. Mag. Vol. 10, Num. 1, pp. S164-S170.

Liu, X.C., Q.Y. Liu, L. Zhou, Q.R. Liu, Z.L. Liu (2014) Chemical composition of Zanthoxylum avicennae essential oil and its larvicidal activity on Aedes albopictus Skuse. Trop. J.Pharm.Res. Vol. 13: Num. 3, pp. 399-404.

Mandal, S., A. Nayak, M. Kar, S.K. Banerjee, A. Das, S.N. Upadhyay, R.K. Singh, A. Banerji, J. Banerji (2010) Antidiarrhoeal activity of carbazole alkaloids from Murraya koenigii Spreng (Rutaceae) seeds. Fitoterapia. Vol. 81, pp. 72-74. 
Misra, L.N., N.A.V. Wouatsa, K. Kumar, R.V. Kumar, F. Tchoumbougnang (2013) Antibacterial, cytotoxic activities and chemical composition of fruits of two Cameroonian Zanthoxylum species. J. Ethnopharm. Vol. 148: Num. 1, pp. 74-80.

Nana, W.L., P. Eke, R. Fokom, I.B. Via, D. Begoude, N.S. Tchameni, T. Tchana, J. Kuate, C. Menut, F.F. Boyom (2015) Activity of Syzygium aromaticum and Zanthoxylum xanthoxyloides essential oils against Phytophthora megakarya. J. Phytophat. Vol. 163: Num. (7-8), pp. 632641.

Negi, J.S., V.K. Bisht, A.K. Bhandari, P. Singh, R.C. Sundriyal (2011) Chemical constituents and biological activities of the genus Zanthoxylum: A review. Afr. J. Pure. Appl. Chem. Vol. 5: Num. 12, pp. 412-416.

Pavani, P., H.S. Ashwini, A. Chittaragi, R. Naika, R. Ashwini, P. Pavani, H. S. Ashok Chittaragi and Raja Naika (2015) Biological and pharmacological properties of Zanthoxylum ovalifolium Weight, leaves (Rutaceae) from different solvents extracts. Int. J. Pharma. Pharma. Res. Vol. 3: Num. 3, pp. 323-338.

Rahman, M.M., A.I. Gray, P. Khondkar, M.A. Islam (2008) Antimicrobial activities of alkaloids and lignans from Zanthoxylum budrunga. Nat. Prod. Commun. Vol. 3: Num. 1, pp. 45-47.

Ruth, T. (2011) Zanthoxylum: A Low-Profile Asian Crop with Great Potential. ECHO Asia Notes. Vol. 8, pp.1-10.

Salah-Fatnassi, K. B.H., F. Hassayoun, I. Cheraif, S. Khan, H.B. Jannet, M. Hammami, M. Aouni, F. Harzallah-Skhiri (2017) Chemical composition, antibacterial and antifungal activities of flowerhead and root essential oils of Santolina chamaecyparissus L., growing wild in Tunisia. Saudi J. Bio. Sci. Vol. 24: Num. 4, pp. 875-882.

Seidemann, J. (2005) World Spice Plants: Economic Usage, Botany, Taxonomy. Springer, Berlin.

Severino, V.G., C.M. Cazal, M.R. Forim, M.F. da Silva, E. Rodrigues-Filho, J.B. Fernandes, P.C. Vieira (2009) Isolation of secondary metabolites from Hortia oreadica (Rutaceae) leaves through high-speed counter-current chromatography. J Chromatogr A. Vol. 1216, pp. 42754281.

Siddique, S., S. Javed, S. Nawaz, Z. Perveen, R.A. Khan, R. Khanum, K. Shahzad (2012), Volatile components and antimicrobial activity of Citrus sinensis var. Mosammi leaves oil, J. Med. Plants Res. Vol. 6: Num. 1, pp. 2184-2187.

Su, J.F., C.J. Guo, J.Y. Wei, J.J. Yang, Y.G. Jiang, Y.F. Li (2003) Protection against hepatic ischemia reperfusion injury in rats by oral pretreatment with quercetin. Biomed. Environ. Sci. Vol. 16, pp. 1-8.

Supabphol, R. and Tangjitjareonkun, J (2014) Review Article Chemical Constituents and Biological Activities of Zanthoxylum limonella (Rutaceae): A Review. Trop. J. Pharm. Res.Vol. 13: Num. 12, pp. 2119-2130.

Thuy, T.T., A. Porsel, H. Ripperger, T.V. Sung, G. Adam (1999) Bishordeninyl terpene alkaloids from Zanthoxylum avicennae. Phytochemistry. Vol. 50: Num 5, pp. 903-907.

Wansi, J.D., J. Wandji, L. Mbaze Meva'a, A.F. Kamdem Waffo, R. Ranjit, S.N. Khan, A. Asma, C.M. Iqbal, M.C. Lallemand, F. Tillequin, Z. (2006) Fomum Tanee. Alpha-glucosidase inhibitory and antioxidant acridone alkaloids from the stem bark of Oriciopsis glaberrima ENGL. (Rutaceae). Chem. Pharm. Bull. (Tokyo). Vol. 54: Num. 3, pp. 292-296. 